\title{
Analisis kemampuan menyelesaikan soal HOTS model TIMSS dan kepercayaan diri siswa sekolah menengah pertama
}

\author{
Gity Wulang Mandini *, Hartono Hartono \\ Program Studi Pendidikan Matematika, Program Pascasarjana, Universitas Negeri Yogyakarta. \\ Jalan Colombo No. 1, Karangmalang, Yogyakarta 55281, Indonesia. \\ * Corresponding Author. E-mail: gitywulangmandini@gmail.com \\ Received: 14 September 2018; Revised: 17 October 2018; Accepted: 21 December 2018
}

\begin{abstract}
Abstrak
Penelitian ini bertujuan menganalisis kemampuan siswa SMP di Kabupaten Wonosobo dalam menyelesaikan soal HOTS model TIMSS dan mendeskripsikan kepercayaan diri siswa SMP di Kabupaten Wonosobo. Penelitian ini termasuk penelitian survei. Populasi penelitian adalah seluruh siswa kelas VIII SMP di Kabupaten Wonosobo pada tahun pelajaran 2016/2017. Pengambilan sampel menggunakan metode stratified proportional random sampling dan diperoleh 99 siswa sebagai sampel yang terbagi dalam 4 sekolah, yaitu 1 sekolah kategori tinggi, 2 sekolah kategori sedang, dan 1 sekolah kategori rendah. Hasil penelitian menunjukkan kemampuan menyelesaikan soal HOTS model TIMSS siswa SMP Kabupaten Wonosobo dalam kategori sedang $(85,9 \%)$. Selanjutnya dilihat untuk masingmasing indikator dari soal HOTS model TIMSS, indikator memadukan/ mensintesis, menganalisis, memberikan alasan, dan menyelesaikan masalah non-rutin berada pada kategori sedang, hanya terdapat 1 indikator yang berada pada kategori rendah yaitu menggeneralisasi. Sedangkan untuk kepercayaan diri siswa SMP di Kabupaten Wonosobo berada pada kategori sedang $(56,6 \%)$. Bila dilihat untuk masing-masing aspek, bahwa aspek keyakinan akan kemampuan diri, optimis, objektif, dan bertanggung jawab berada pada kategori sedang, untuk aspek rasional dan realistis berada pada kategori rendah
\end{abstract}

Kata Kunci: kemampuan siswa, kepercayaan diri, HOTS, TIMSS

\section{An analysis of junior high school students'ability in solving HOTS model TIMSS and self-confidence}

\begin{abstract}
The purpose of this study were to analyze the ability of junior high school students in Wonosobo to solve the HOTS model TIMSS problem and to describe the self-confidence of junior high school students in Wonosobo. This study was a survey. The population was all 8th grade of Wonosobo Junior High School in the academic year 2016/2017. Sampling used was stratified proportional random sampling method. The samples consisted of 99 students from 4 representative schools, namely 1 school for high category, 2 schools for medium cateogry, and 1school for low category. The results showed that the ability to solve the HOTS model TIMSS problem of junior high school students in Wonosobo was in the medium category (85.9\%). Furthermore, for each indicator of HOTS model TIMSS problem, found that indicators integrate/ synthesize, analyze, justify, and solve non-routine problems were in medium category, there was only 1 indicator that in low category that is generalization. As for selfconfidence of junior high school students in Wonosobo was in medium category (56.6\%). When viewed from each aspects, aspect of belief in self-ability, optimist, objective, and responsible were in medium category, aspect of rational and realisticis was in low category.
\end{abstract}

Keywords: students' ability, self-confidence, HOTS, TIMSS

How to Cite: Mandini, G., \& Hartono, H. (2018). Analisis kemampuan menyelesaikan soal HOTS model TIMSS dan kepercayaan diri siswa sekolah menengah pertama. Pythagoras: Jurnal Pendidikan Matematika, 13(2), 148157. doi:https://doi.org/10.21831/pg.v13i2.21234

doi)

https://doi.org/10.21831/pg.v13i2.21234

\section{PENDAHULUAN}

Salah satu permasalahan pendidikan yang dihadapi oleh Bangsa Indonesia saat ini ialah rendahnya mutu pendidikan pada setiap jenjang dan satuan pendidikan, khususnya pendidikan dasar dan menengah. Berdasarkan data dalam 
Education For All (EFA) Global Monitoring Report 2011: Di Balik Krisis: Konflik Militer dan Pendidikan yang dikeluarkan Organisasi Pendidikan, Ilmu Pengetahuan, dan Kebudayaan Perserikatan Bangsa-Bangsa yang diluncurkan di New York, Amerika Serikat menunjukkan bahwa indeks pembangunan pendidikan (Education Development Index) menurut data adalah 0,934. Nilai ini menempatkan Indonesia di posisi ke-69 dari 127 negara di dunia (Anonim, 2011). Hal ini mengindikasikan masih rendahnya kualitas pendidikan di Indonesia.

Rendahnya kualitas pendidikan di Indonesia termasuk pada pendidikan matematika. Matematika merupakan mata pelajaran wajib pada jenjang pendidikan dasar dan menengah di Indonesia. Kemampuan matematika diperlukan untuk secara kognitif membantu siswa untuk dapat berpikir logis. TIMSS (Trends in International Mathematics and Science Study) merupakan studi lintas negara yang dilaksanakan oleh IEA (International Association for the Evaluation of Educational Achievement) setiap empat tahunan. TIMSS bertujuan untuk mengetahui peningkatan pembelajaran matematika dan sains dalam kurikulum sekolah yang diselenggarakan setiap empat tahun sekali.

Kerangka penilaian kemampuan siswa di bidang matematika yang diukur TIMSS dibagi dalam dua kelompok yaitu domain konten dan domain kognitif dengan memperhatikan kurikulum yang berlaku di negara tersebut. Domain konten terdiri dari bilangan, aljabar, geometri, dan data dan peluang. Sedangkan domain kognitif terdiri domain pengetahuan, penerapan dan penalaran (Mullis, Martin, Foy \& Arora, 2012, p.30).

TIMSS pada tahun 2011 menitikberatkan pada kemampuan knowing (pengetahuan) sebanyak $35 \%$, applying (penerapan) sebanyak $40 \%$, dan reasoning (penalaran) sebanyak 25\% (Mullis et al., 2012, p.6). Berdasarkan hasil TIMSS pada tahun 2011 kemampuan penalaran matematis siswa kelas VIII di Indonesia masih di bawah rata-rata internasional, yaitu hanya $17 \%$ yang menjawab benar, sedangkan rata-rata internasional sebanyak 30\% (Mullis et al., 2012, p.462).

Mutu pendidikan matematika di Indonesia yang masih rendah juga diungkapkan oleh Adiyanti (2016). Beliau mengatakan bahwa rendahnya mutu pendidikan matematika tidak terlepas dari adanya kesulitan belajar pada siswa terutama mengembangkan kemampuan-kemampuan dalam menyelesaikan soal. Soal dengan indikator menganalisis, mengevaluasi dan meng- kreasi sedikit sekali terdapat dalam buku penunjang. Hal ini diperkuat juga dengan pendapat Winataputra (dalam Riadi \& Retnawati, 2014, p.127) tentang penelitian TIMSS yang menunjukkan masih rendahnya prestasi siswa Indonesia dalam matematika, terutama terkait soal-soal Higher Order Thinking Skills (HOTS).

Pembelajaran matematika di Indonesia belum sepenuhnya fokus pada pengembangan HOTS. Guru mengawali pembelajaran matematika hanya dengan mengenalkan definisi dan rumus-rumus tanpa menghubungkannya dengan penyelesaian masalah dalam berbagai konteks. Guru juga belum melaksanakan pembelajaran yang menekankan keterampilan berpikir tingkat tinggi. Pada praktiknya HOTS sangat diperlukan peserta didik, karena permasalahan dalam kehidupan sesungguhnya (real life problems) bersifat kompleks, tidak terstruktur, rumit, baru, dan memerlukan keterampilan berpikir yang lebih dari sekedar mengaplikasikan apa yang telah dipelajari (Riadi \& Retnawati, 2014, p.127).

HOTS merupakan suatu keterampilan berpikir yang tidak hanya membutuhkan keterampilan mengingat, tetapi membutuhkan keterampilan lain yang lebih tinggi. Indikator untuk mengukur HOTS meliputi keterampilan menganalisis, mengevaluasi, dan menciptakan (Anderson \& Krathwohl, 2001, p.68). Pengembangan keterampilan berpikir tingkat tinggi peserta didik akan menghasilkan kemahiran peserta didik dalam strategi pemecahan masalah menjadi baik, tingkat keyakinan peserta didik dalam matematika meningkat, dan prestasi belajar peserta didik pada masalah non-rutin yang menuntut keterampilan berpikir tingkat tinggi meningkat (Butkowski, Corrigan, Nemeth, \& Spencer, 1994, p.10). Sehingga siswa dapat belajar lebih mendalam dan memahami konsep dengan lebih baik dalam pembelajaran matematika. Salah satu studi kelanjutan yang dapat mengukur perkembangan kemampuan siswa dalam bidang matematika dan sains yaitu TIMSS. HOTS model TIMSS diharapkan dapat meningkatkan kemampuan dan prestasi siswa dalam bidang matematika dan sains.

King, Godson, dan Rohani (2013, p.32) menyatakan bahwa di dalam Higher Order Thinking Skills termuat berpikir kritis, logis, reflektif, metakognisi dan kreatif. Keterampilan tersebut akan aktif saat orang tersebut berhadapan dengan suatu masalah yang tidak biasa, ketidakpastian, pertanyaan dan adanya pilihan. Bila penerapan dari keterampilan tersebut sukses akan terlihat di dalam penjelasan, keputusan, 
penampilan, dan produk yang valid sesuai dengan konteks dari pengetahuan dan pengalaman yang ada serta lanjutan perkembangan keterampilan ini atau keterampilan intelektual lainnya.

Siswa pada dasarnya ingin meraih prestasi dalam pembelajaran. Walgito (2004, p.124) menyebutkan bahwa terdapat beberapa faktor yang harus diperhatikan dalam pembelajaran, yaitu faktor fisik dan faktor psikis. Faktor psikis meliputi motif, minat, konsentrasi, perhatian, natural curiosity, balance personality, self-confidence, intelegensi, dan ingatan.

Kepercayaan diri (self-confidence) diartikan sebagai keyakinan terhadap kemampuan yang dimiliki. Rasa percaya diri merupakan suatu keyakinan diri dan kemampuan akan diri sendiri dalam mencapai kesuksesan. Rasa kepercayaan diri tersebut juga merupakan keyakinan bila akan melakukan suatu hal dengan benar, sesuai, dan dengan cara yang efektif (McElmeel, 2002, p.27).

Faktanya masih banyak siswa yang memiliki self-confidence yang rendah. Hal itu ditunjukkan oleh hasil studi TIMSS (Mullis, et al, 2012, p.338) yang menyatakan bahwa dalam skala internasional hanya $14 \%$ siswa yang memiliki self-confidence tinggi terkait kemampuan matematikanya, sedangkan $45 \%$ siswa termasuk dalam kategori sedang. Hal serupa juga terjadi pada siswa di Indonesia. Dari hasil studi TIMSS hanya $3 \%$ siswa yang memiliki self-confidence tinggi dalam matematika, sedangkan 52\% termasuk dalam kategori siswa dengan self-confidence sedang. Kepercayaan diri seorang siswa merupakan faktor internal yang mempengaruhi proses pembelajaran. Apabila siswa dalam proses pembelajaran mampu menyelesaikan permasalahan dengan mengoptimalkan segala kemampuan yang dimiliki oleh siswa, maka akan menumbuhkan rasa kepercayaan diri yang tinggi pada mata pelajaran matematika (Ameliah, Munawaroh, \& Muchyidin, 2016, p.10).

Kabupaten Wonosobo merupakan salah satu kabupaten di Jawa Tengah. Hasil ujian nasional (UN) untuk tingkat SMP/SMPLB/MTs di Kabupaten Wonosobo mengalami kenaikan yang cukup signifikan. Berdasarkan data bahwa hasil UN SMP di Wonosobo mengalami kenaikan dari tahun ke tahun. Namun demikian, apabila melihat nilai ujian nasional pada mata pelajaran matematika tingkat SMP di Kabupaten Wonosobo belum mengalami peningkatan. Hal ini dapat dilihat dari masih adanya persentase siswa yang tidak lulus pada mata pelajaran matematika. Persentase siswa yang tidak lulus ujian nasional pada mata pelajaran matematika tingkat SMP di Kabupaten Wonosobo justru mengalami peningkatan pada kurun waktu 2 tahun terakhir.

Berdasarkan studi pendahuluan pada beberapa SMP di Kabupaten Wonosobo melalui wawancara yang dilakukan peneliti dengan guru matematika di beberapa SMP Kabupaten Wonosobo menyimpulkan bahwa rata-rata kemampuan penalaran matematis siswa tergolong rendah. Hal ini terlihat dari ketidakmampuan sebagian besar siswa menyelesaikan soal matematika ketika soal tersebut sedikit berbeda dengan contoh yang diberikan oleh guru. Budiman dan Jailani (2014, p.142) mengemukakan bahwa permasalahan yang terjadi di sekolah yaitu soal-soal cenderung lebih banyak menguji aspek ingatan yang kurang melatih keterampilan berpikir tingkat tinggi peserta didik, kemampuan berpikir anak Indonesia secara ilmiah dianggap masih rendah. Salah satu faktor penyebabnya antara lain karena peserta didik di Indonesia kurang terlatih dalam menyelesaikan soal-soal yang mengukur HOTS.

Kemampuan siswa dalam menyelesaikan soal juga didukung dengan hasil penelitian yang dilakukan oleh Romadhon (2015, p.167) bahwa siswa SMP di Kabupaten Wonosobo dengan kemampuan komunikasi matematis subjek prestasi tinggi menempati kategori sedang karena mampu menyelesaikan soal dengan baik meskipun terdapat soal yang belum dapat dijawab dengan tepat. Siswa dalam subjek prestasi sedang menempati kategori kurang karena dalam mengkomunikasikan hasil pekerjaannya kurang lengkap. Sedangkan siswa dengan subjek prestasi rendah menempati kategori sedang karena belum mampu mengerjakan dengan maksimal dan hasil yang tepat terutama soal hitungan.

Hasil observasi pada beberapa SMP di Kabupaten Wonosobo juga menunjukkan bahwa siswa jarang menunjukkan kepercayaan diri khususnya dalam pembelajaran matematika. Bila self-confidence dalam diri siswa kurang, maka akan memberikan dampak negatif bagi siswa. Siswa akan merasa tidak yakin terhadap kemampuannya bila ia tidak memiliki selfconfidence yang tinggi. Hal tersebut kemudian akan menimbulkan sikap mudah putus asa dan enggan berusaha ketika belajar. Ketika siswa menyelesaikan soal yang diberikan kemudian mengalami kesulitan, siswa cenderung memilih untuk menunggu jawaban yang diberikan oleh guru atau bahkan hanya melihat dan menyalin jawaban temannya. Hal tersebut tentu akan 
berpengaruh kepada hasil belajar yang kurang optimal (Martyanti, 2016, p.5).

Berdasarkan paparan tersebut dilakukan penelitian dengan tujuan untuk menganalisis kemampuan siswa SMP di Kabupaten Wonosobo dalam menyelesaikan soal HOTS model TIMSS dan mendeskripsikan kepercayaan diri siswa SMP di Kabupaten dalam pembelajaran matematika. Sehingga diperoleh manfaat adalah sebagai berikut. Bagi siswa, pembelajaran matematika dengan menyelesaikan soal HOTS model TIMSS diharapkan dapat melatih dan mengembangkan kemampuan penalaran matematis siswa khususnya indikator menganalisis, mengevaluasi dan mengkreasi. Bagi guru, dapat menjadi alternatif pilihan bagi para guru matematika dalam mengembangkan soal HOTS model TIMSS.

\section{METODE}

Penelitian ini merupakan penelitian deskriptif dengan pendekatan survei. Penelitian dilaksanakan pada bulan Maret hingga April 2017 pada 4 SMP di Kabupaten Wonosobo. Populasi penelitian adalah seluruh siswa kelas VIII SMP di Kabupaten Wonosobo pada tahun pelajaran 2016/2017. Pengambilan sampel dilakukan dengan menggunakan teknik sampel acak proporsional berstrata (stratified proportional random sampling) yang merupakan gabungan dari teknik sampling bertingkat (stratified sampling) dan teknik sampling proporsional (proportional sampling) yang dilanjutkan dengan teknik sampling acak (random sampling). Teknik sampling proporsional digunakan untuk menentukan sampel secara proporsional untuk setiap strata. Besar sampel yang diperoleh adalah 99 siswa yang terbagi dalam 4 sekolah, yaitu 1 sekolah kategori tinggi, 2 sekolah kategori sedang, dan 1 sekolah kategori rendah.

Teknik pengumpulan data yang digunakan dalam penelitian adalah tes dan angket. Tes digunakan untuk mengumpulkan data tentang jawaban dan langkah pengerjaan yang dilakukan siswa dalam menyelesaikan soal HOTS dengan model TIMSS. Instrumen tes berupa soal HOTS model TIMSS. Kisi-kisi soal HOTS model TIMSS mencakup dua domain yaitu domain konten yang terdiri dari bilangan, aljabar, geometri, data dan peluang serta domain kognitif berupa penalaran. Banyak soal 20 butir yang terdiri dari 7 soal pilihan ganda, 10 soal isian singkat, dan 3 soal uraian.

Angket digunakan untuk mengumpulkan data atau informasi tentang kepercayaan diri siswa. Angket berupa angket tertutup, yang sudah disediakan jawaban sehingga responden tinggal memilih. Angket terdiri dari 30 pernyataan dengan kisi-kisi pada Tabel 1. Skala angket kepercayaan diri menggunkan skala Likert dengan alternatif jawaban adalah Sangat Sesuai (SS), Sesuai(S), Cukup Sesuai (CS), Tidak Sesuai (TS) dan Sangat Tidak Sesuai (STS).

Tabel 1. Kisi-kisi Angket Kepercayaan Diri

\begin{tabular}{|c|c|}
\hline Aspek & Indikator \\
\hline $\begin{array}{l}\text { Keyakinan akan } \\
\text { kemampuan diri }\end{array}$ & $\begin{array}{l}\text { - Bersungguh-sungguh akan } \\
\text { apa yang dilakukannya }\end{array}$ \\
\hline Optimis & $\begin{array}{l}\text { - Selalu berpandangan baik } \\
\text { dalam menghadapi segala hal } \\
\text { tentang diri dan } \\
\text { kemampuannya }\end{array}$ \\
\hline Objektif & $\begin{array}{l}\text { - Memandang permasalahan } \\
\text { sesuai dengan kebenaran } \\
\text { semestinya }\end{array}$ \\
\hline $\begin{array}{l}\text { Bertanggung } \\
\text { jawab }\end{array}$ & $\begin{array}{l}\text { - Bersedia menanggung segala } \\
\text { sesuatu yang menjadi } \\
\text { konsekuensinya }\end{array}$ \\
\hline $\begin{array}{l}\text { Rasional dan } \\
\text { realistis }\end{array}$ & $\begin{array}{l}\text { - Menganalisa terhadap } \\
\text { masalah dengan } \\
\text { menggunakan pemikiran yang } \\
\text { diterima akal sesuai kenyataan }\end{array}$ \\
\hline
\end{tabular}

Uji validitas yang digunakan adalah validitas isi dan konstruk. Pengukuran validitas isi dengan bantuan dua dosen ahli dalam matematika. Validitas konstruk menggunakan analisis faktor. Berdasarkan hasil uji validitas pada instrumen tes kemampuan menyelesaikan soal HOTS model TIMSS dan instrumen angket kepercayaan diri menunjukkan bahwa seluruh item valid. Hasil uji reliabilitas menunjukkan bahwa instrumen tes soal HOTS model TIMSS dan instrumen angket kepercayaan diri berada dalam kategori sangat tinggi, dengan estimasi nilai reliabilitas sebesar 0,887 untuk soal HOTS model TIMSS dan 0,918 untuk angket kepercayaan diri.

Analisis data yang digunakan berupa statistik deskriptif. Analisis berupa deskripsi nilai yang diperoleh masing-masing kelas dalam bentuk rata-rata, nilai maksimum, nilai minimum dan standar deviasi dengan langkah-langkah sebagai berikut membuat tabulasi skor data, mengkonversi skor kepercayaan diri ke dalam nilai 0-100, menentukan nilai kemampuan menyelesaikan soal HOTS, menentukan nilai maksimum dan nilai minimum, menentukan nilai rata-rata kelas dan menghitung standar deviasi.

Distribusi kategori untuk nilai kemampuan menyelesaikan soal HOTS model TIMSS dan kepercayaan diri siswa menggunakan kriteria sebagai pada Tabel 2. 
Tabel 2. Distribusi Kategori

\begin{tabular}{|c|c|c|}
\hline & Skor & Intepretas \\
\hline & $\mathrm{X} \geq$ Mean $+1 \mathrm{Sd}$ & Tinggi \\
\hline & Mean-1Sd $\leq \mathrm{X}<$ Mean+1Sd & Sedang \\
\hline & $X<$ Mean-1Sd & Rendah \\
\hline \multicolumn{3}{|c|}{ (Azwar, 2013, p.149) } \\
\hline $\mathrm{X}$ & \multicolumn{2}{|c|}{$=\quad$ nilai yang diperoleh siswa. } \\
\hline Mean & \multicolumn{2}{|c|}{$=$ rata-rata. } \\
\hline $\mathrm{SD}$ & \multicolumn{2}{|l|}{$=$ standar deviasi. } \\
\hline
\end{tabular}

\section{HASIL DAN PEMBAHASAN}

\section{Kemampuan Menyelesaikan Soal HOTS Model TIMSS}

Data variabel kemampuan menyelesaikan soal HOTS model TIMSS diperoleh melalui tes dengan 20 butir soal yang dibagi dalam 5 indikator yaitu memadukan/mensintesis, menganalisis, menggeneralisasi, memberikan alasan dan menyelesaikan masalah non-rutin. Berdasarkan data kemampuan menyelesaikan soal HOTS Model TIMSS diperoleh nilai tertinggi sebesar 65,00 dan nilai terendah sebesar 20,00. Hasil analisis menunjukkan rerata (mean) sebesar 42,44, median 40,00, modus 33,00 dan standar deviasi sebesar 11,75.

Berikut kategorisasi kemampuan menyelesaikan soal HOTS Model TIMSS siswa SMP di Kabupaten Wonosobo. Berdasarkan Tabel 3 menunjukkan bahwa kemampuan menyelesaikan soal HOTS model TIMSS pada kategori sedang sebanyak 85 siswa $(85,9 \%)$ dan dalam kategori rendah sebanyak 14 siswa $(14,1 \%)$. Sementara untuk kategori tinggi tidak ada. Dengan demikian, kemampuan menyelesaikan soal HOTS model TIMSS pada siswa kelas VIII SMP di Kabupaten Wonosobo berada pada kategori sedang.

Tabel 3. Kategorisasi Kemampuan Menyelesaikan Soal HOTS Model TIMSS

\begin{tabular}{lcc}
\hline \multicolumn{1}{c}{ Kategori } & Frekuensi & Persentase \\
\hline Tinggi & 0 & $0,0 \%$ \\
Sedang & 85 & $85,9 \%$ \\
Rendah & 14 & $14,1 \%$ \\
\hline & 99 & $100,00 \%$ \\
\hline
\end{tabular}

Hasil penelitian yang diperoleh hampir sama dengan hasil penelitian yang dilakukan oleh Ayuningtyas dan Rahaju (2014, p.1) yang menyimpulkan bahwa kemampuan siswa dalam menyelesaikan soal HOT materi aljabar bervariasi, terdapat siswa yang tidak dapat menyelesaikan soal dengan indikator analysis. Namun ada pula siswa yang memiliki kemampuan hampir dapat memenuhi semua indikator analysis, evaluate, dan create dalam penyelesaian soal HOT.

Sebanyak 4 sekolah dipilih berdasarkan strata yaitu 1 sekolah dari kategori tinggi (A), 2 sekolah dari kategori sedang (B), dan 1 sekolah dari kategori rendah (C). Berdasarkan strata sekolah tersebut diperoleh perbandingan rata-rata nilai kemampuan menyelesaikan soal HOTS model TIMSS pada masing-masing strata sekolah disajikan sebagai berikut.

Tabel 4. Perbandingan Rata-Rata Nilai Kemampuan Menyelesaikan Soal HOTS Model TIMSS untuk Masing-Masing Strata Sekolah

\begin{tabular}{ccc}
\hline No. & Kategori & Rata-rata \\
\hline 1. & A & 49,76 \\
2. & B & 40,51 \\
3. & C & 39,56 \\
\hline
\end{tabular}

Berdasarkan Tabel 4, sekolah dengan kategori A memperoleh rata-rata paling tinggi. Kemudian sekolah dengan kategori B memperoleh rata-rata sebesar 40,51. Sekolah kategori C memperoleh rata-rata paling rendah sebesar 39,56. Hal ini berarti sekolah dengan kategori A memiliki kemampuan menyelesaikan soal HOTS model TIMSS lebih baik dibandingkan sekolah yang berkategori B dan C.

Kemampuan menyelesaikan soal HOTS model TIMSS pada siswa kelas VIII SMP di Kabupaten Wonosobo meliputi lima indikator yaitu memadukan/mensintesis, menganalisis, menggeneralisasi, memberikan alasan, dan menyelesaikan masalah non-rutin (Mullis, Marton, Ruddock, O’Sullivan, \& Preuschoff, 2009, p.46). Berikut kategorisasi masing-masing indikator dalam kemampuan menyelesaikan soal HOTS model TIMSS pada siswa kelas VIII SMP di Kabupaten Wonosobo.

Tabel 5. Hasil Kategorisasi Indikator Menyelesaikan Soal HOTS Model TIMSS

\begin{tabular}{lccc}
\hline \multirow{2}{*}{ Indikator } & \multicolumn{3}{c}{ Hasil } \\
\cline { 2 - 4 } & Tinggi & Sedang & Rendah \\
\hline Memadukan/ & $0 \%$ & $96 \%$ & $4 \%$ \\
mensintesis & $20,2 \%$ & $67,7 \%$ & $12,1 \%$ \\
$\begin{array}{l}\text { Menganalisis } \\
\text { Menggeneralisasi }\end{array}$ & $4,04 \%$ & $34,34 \%$ & $61,62 \%$ \\
$\begin{array}{l}\text { Memberikan } \\
\text { alasan }\end{array}$ & $17,2 \%$ & $71,7 \%$ & $11,1 \%$ \\
$\begin{array}{l}\text { Menyelesaikan } \\
\text { masalah non-rutin }\end{array}$ & $0 \%$ & $50,5 \%$ & $49,5 \%$ \\
\hline
\end{tabular}

Tabel 5 menunjukkan bahwa pada indikator mensintesis, menganalisis, memberikan alasan dan menyelesaikan masalah non-rutin masuk kategori sedang. Sedangkan untuk 
Pythagoras, 13 (2), 2018 - 153

Gity Wulang Mandini, Hartono Hartono

indikator menggeneralisasikan masuk kategori rendah.

Soal nomor 1 merupakan soal pada domain konten bilangan dengan indikator memadukan/ mensintesis. Berikut diberikan salah satu jawaban siswa.

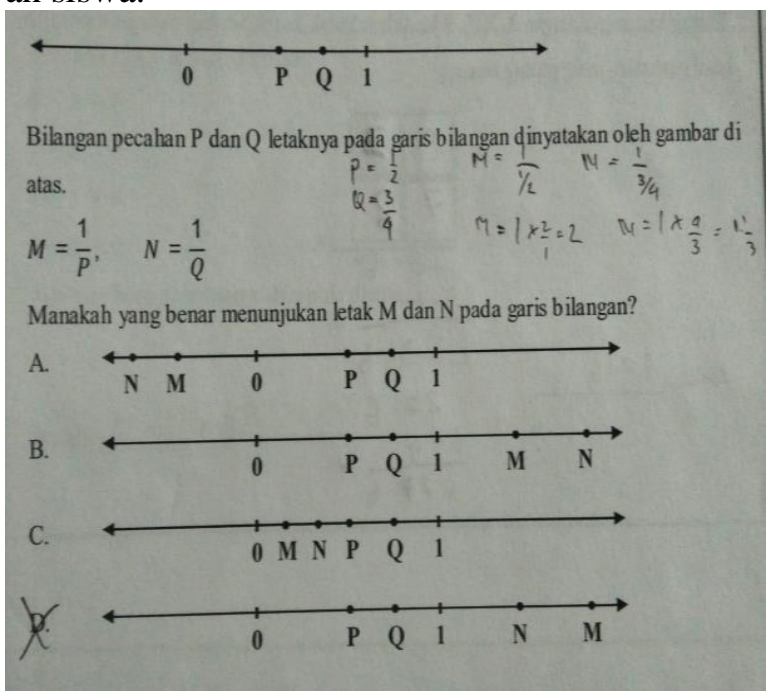

Gambar 1. Hasil Pekerjaan Benar Siswa Soal Nomor 1

Sebanyak 61 siswa dapat menjawab soal nomor 1 dengan benar. Gambar 1 menunjukkan bahwa siswa mampu menjawab soal dengan benar. Berdasarkan jawaban tersebut, siswa mampu merepresentasikan informasi pada soal dengan memisalkan bilangan yang sesuai dengan informasi bahwa $0<P<Q<1$, misalnya $P=$ $\frac{1}{2}$ dan $Q=\frac{3}{4}$. Selanjutnya siswa menggunakan informasi tersebut untuk merepresentasikan nilai $\mathrm{M}$ dan $\mathrm{N}$ sesuai hubungan yang diketahui, diperoleh $M=\frac{1}{P}=2$ dan $N=\frac{1}{Q}=\frac{4}{3}$. Sehingga diperoleh jawaban $\mathrm{D}$, yaitu $1<N<M$.

Hasil analisis kemampuan siswa dalam menyelesaikan soal HOTS model TIMSS menunjukkan bahwa siswa memiliki kemampuan kategori sedang dalam memadukan/mensintesis. Hal ini juga terlihat dari jawaban siswa yang mampu mensistesis soal dengan baik. Hal ini berarti siswa telah mampu membuat hubungan di antara elemen pengetahuan yang berbeda dan representasi yang berhubungan atau menghubungkan di antara ide-ide matematika.

Soal nomor 2 merupakan soal pada domain konten bilangan dengan indikator menganalisis. Salah satu jawaban siswa adalah sebagai berikut.

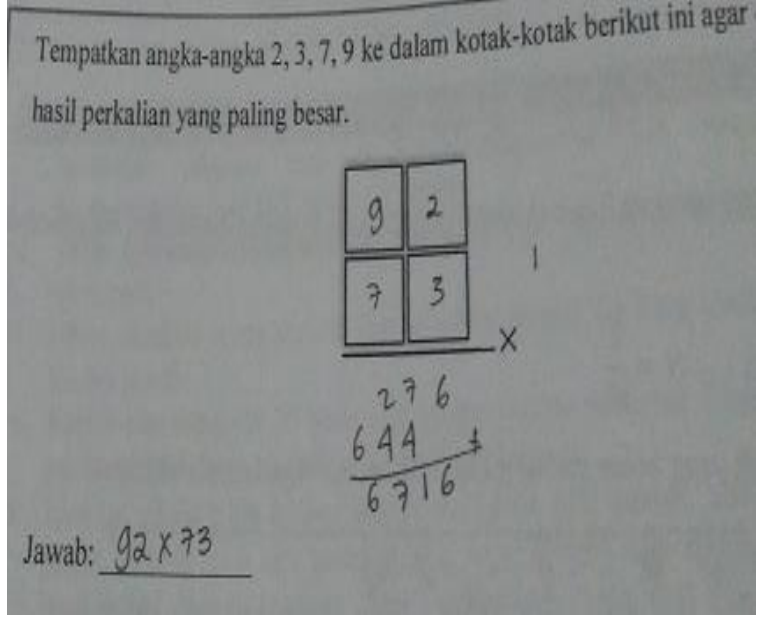

Gambar 2. Hasil Pekerjaan Benar Siswa Soal Nomor 2

Sebanyak 96 siswa dapat menjawab soal nomor 2 dengan benar, hanya 3 siswa yang salah menjawab. Gambar 2 menunjukkan jawaban yang diberikan siswa benar. Berdasarkan Gambar 2, siswa mampu menganalisis dengan baik. Siswa mampu mecari pasangan yang tepat agar mememperoleh hasil perkalian terbesar.

Hasil penelitian menunjukkan bahwa siswa memiliki kemampuan sedang dalam menganalisis soal. Berdasarkan jawaban siswa pada Gambar 2, siswa telah dapat menentukan, mendeskripsikan atau menggunakan hubungan antara variabel atau objek matematika dan mengambil kesimpulan dari informasi yang diberikan.

Soal nomor 6 merupakan soal pada domain konten aljabar dengan indikator menggeneralisasi. Berikut diberikan salah satu jawaban siswa.

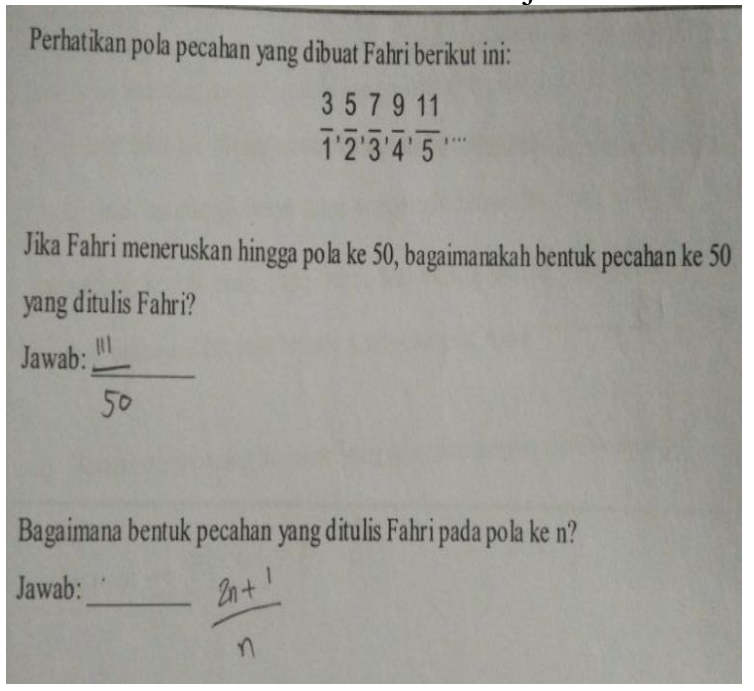

Gambar 3. Hasil Pekerjaan Salah Siswa Soal Nomor 6

Berdasarkan hasil pekerjaan siswa nomor 6, sebanyak 24 siswa menjawab salah, 52 siswa menjawab kurang sempurna, dan 23 siswa men- 
Pythagoras, 13 (2), 2018 - 154

Gity Wulang Mandini, Hartono Hartono

jawab benar. Gambar 3 merupakan salah satu jawaban siswa yang memperoleh nilai kurang sempurna. Siswa mampu menggeneralisasi pola dengan baik sehingga diperoleh bentuk pecahan ke-n. Terjadi ketidak telitian saat siswa melakukan perhitungan pola ke-50. Seharusnya diperoleh pola ke-50 adalah $\frac{101}{50}$, namun jawaban yang diperoleh siswa adalah $\frac{111}{50}$.

Soal nomor 7 merupakan soal pada domain konten aljabar dengan indikator menggeneralisasi. Berikut diberikan salah satu jawaban siswa.

Tabel berikut ini menunjukkan hasil susunan yang diperoleh Rudi. Lengkapilah
kolom tabel yang masih kosong sesuai dengan pola susunan yang dilakukan Rudi.
\begin{tabular}{|c|c|c|c|}
\hline Susunan ke- & Segitiga Putih & Segitiga Hitam & Jumlah Segitiga \\
\hline 1 & 0 & 1 & $1+3$ \\
\hline 2 & 1 & 3 & 4 \\
\hline 3 & 3 & 6 & 9 \\
\hline 4 & 6 & 10 & $16+9$ \\
\hline 5 & 10 & 15 & 2.5 \\
\hline 6 & 15 & 24 & 36 \\
\hline$\vdots$ & $\vdots$ & $\vdots$ & $\vdots$ \\
\hline $\mathrm{n}$ & $\ldots$ & $\ldots$ & $\ldots$ \\
\hline
\end{tabular}

Gambar 4. Hasil Pekerjaan Kurang Sempurna Siswa Soal Nomor 7

Berdasarkan jawaban siswa soal nomor 7 , sebanyak 3 siswa yang menjawab salah, 81 siswa menjawab kurang sempurna, dan 15 siswa menjawab benar. Gambar 4 menunjukkan jawaban siswa yang kurang sempurna. Siswa sudah mampu menentukan barisan pada suku selanjutnya, akan tetapi masih belum dapat menggeneralisasi ke bentuk yang lebih umum pola barisan pada suku ke-n. Akibatnya siswa tidak menentukan pola barisan pada suku ke-n.

Sementara kemampuan siswa dalam menggeneralisasi soal termasuk dalam kategori rendah. Siswa masih kesulitan untuk memperluas domain hasil yang diperoleh dari proses berpikir matematis dan memecahkan masalah yang dapat digeneralisasikan lebih umum atau spesifikasikan untuk hal tertentu.

Soal nomor 11 merupakan soal pada domain konten geometri dengan indikator memberikan alasan. Salah satu jawaban siswa terlihat pada Gambar 5.

Berdasarkan jawaban siswa pada soal nomor 11, sebanyak 65 siswa menjawab benar dan 34 siswa menjawab salah. Gambar 5 menunjukkan siswa mampu menjawab soal nomor 11 dengan benar. Siswa menjawab soal dengan menerapkan konsep segitiga tumpul, yaitu segitiga dengan panjang sisi a, b, dan c dengan yang terpanjang adalah $\mathrm{c}$, yang merupakan segitiga tumpul apabila $c^{2}>a^{2}+b^{2}$. Segitiga yang akan dibentuk Raisa memiliki panjang sisi $60 \mathrm{~cm}, 70$ $\mathrm{cm}$, dan $100 \mathrm{~cm}$, memenuhi pertidaksamaan $100^{2}>60^{2}+70^{2}$. Sehingga segitiga yang akan dibentuk Raisa merupakan segitiga tumpul. Hal ini menunjukkan bahwa konsep jenis-jenis segitiga telah dikuasai siswa dengan baik. Sehingga siswa dapat menentukan jenis segitiga beserta alasan yang tepat. Hal ini berarti siswa sudah dapat memberikan alasan dengan acuan atau referensi terhadap hasil pekerjaan matematika.

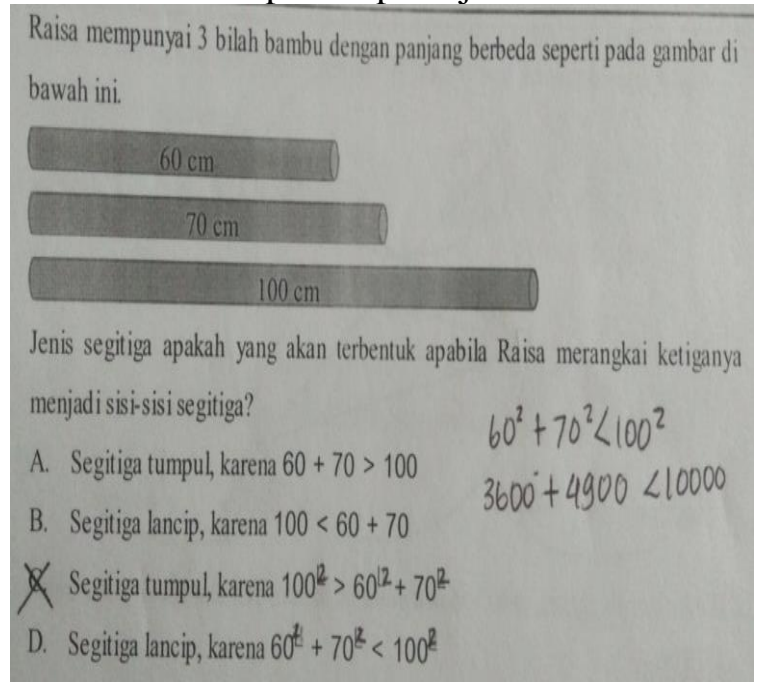

Gambar 5. Hasil Pekerjaan Benar Siswa Soal Nomor 11

Soal nomor 4 merupakan soal pada domain konten bilangan dengan indikator menyelesaikan masalah non-rutin. Berikut diberikan salah satu jawaban siswa.

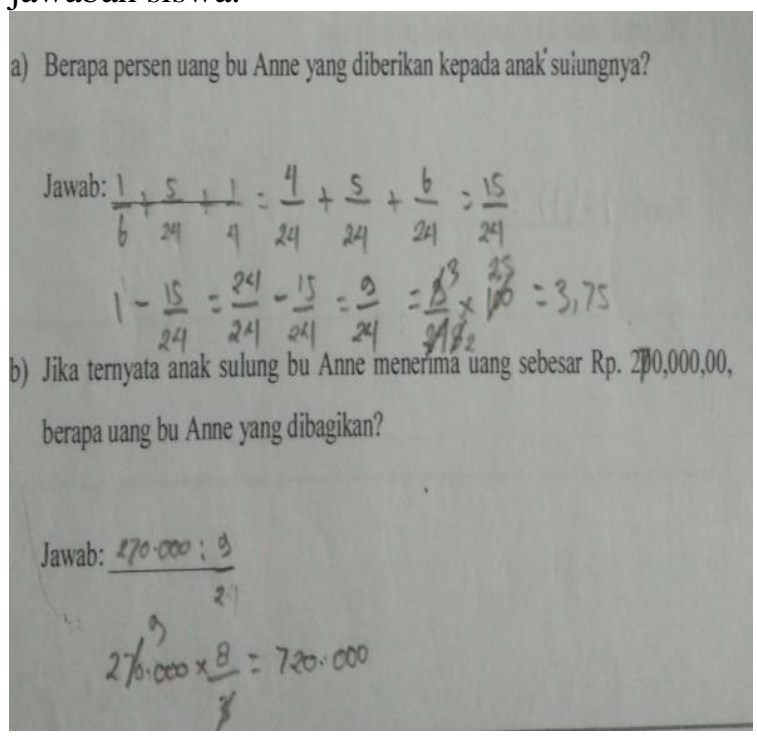

Gambar 6. Hasil Pekerjaan Siswa Soal Nomor 4

Berdasarkan jawaban siswa pada soal nomor 4, sebanyak 51 siswa menjawab benar sempurna, 40 siswa menjawab kurang sempurna, 
Pythagoras, 13 (2), 2018 - 155

Gity Wulang Mandini, Hartono Hartono

dan 8 siswa menjawab salah. Gambar 6 menunjukkan jawaban siswa yang salah pada soal nomor 4a. Siswa tersebut sudah dapat menyatakan bagian yang diperoleh anak sulung bu Anne dalam bentuk pecahan, tetapi salah dalam mengubah jawaban ke dalam bentuk persentase. Siswa menjawab 3,75\%, padahal jawaban yang seharusnya adalah 37,5\%. Selanjutnya siswa tersebut dapat menjawab benar pertanyaan pada soal 4b meskipun salah dalam menjawab soal 4a. Hal ini dikarenakan untuk menyelesaikan soal $4 \mathrm{~b}$, siswa tersebut menggunakan perbandingan dalam bentuk pecahan, bukan menggunakan hasil persentase yang diperoleh berdasarkan jawaban 4a. Berdasarkan jawaban tersebut, siswa sudah dapat menyelesaikan persoalan non-rutin yang diberikan, akan tetapi siswa masih salah dalam mengubah bentuk pecahan menjadi bentuk persen.

Soal HOTS model TIMSS dalam pembelajaran matematika sangat penting karena membekali siswa dengan kemampuan berpikir logis, analitis, sistematis, kritis, dan kreatif, serta kemampuan bekerja sama. Dengan memberikan soal HOTS kepada siswa SMP tentunya siswa akan terbiasa menganalisis sehingga mampu menyelesaikan masalah-masalah non-rutin dalam soal matematika. Hal ini sebagaimana dengan pendapat Thomas dan Thorne (2011, p.32) yang mengemukakan bahwa dengan HOTS keterampilan dan karakter siswa dapat ditingkatkan, dan dengan pembelajaran HOTS maka dapat membiasakan siswa menggunakan pemikiran tingkat tinggi.

Berdasarkan uraian yang telah dikemukakan sebelumnya dapat disimpulkan bahwa kemampuan menyelesaikan soal HOTS model TIMSS pada siswa SMP Kabupaten Wonosobo dalam kategori sedang. Meskipun masuk kategori sedang, namun siswa dapat menyelesaikan soal masalah non-rutin dengan baik meskipun belum sempurna. Kemampuan menyelesaikan soal HOTS model TIMSS dapat meningkatkan keterampilan dan karakter siswa, membiasakan siswa menggunakan pemikiran tingkat tinggi, berpikir kritis, kreatif, memiliki kemampuan memecahkan masalah, siswa akan belajar lebih mendalam, siswa akan memahami konsep lebih baik.

\section{Kepercayaan Diri}

Berdasarkan data kepercayaan diri diperoleh nilai tertinggi sebesar 53,00 dan nilai terendah sebesar 10,00. Hasil analisis menunjukkan rerata (mean) sebesar 32,65, median 34,00, modus 38 dan standar deviasi sebesar 9,16.
Tabel 6. Kategorisasi Kepercayaan Diri

\begin{tabular}{clcc}
\hline No. & Kategori & Frekuensi & Persentase \\
\hline 1 & Tinggi & 0 & $0,0 \%$ \\
2 & Sedang & 56 & $56,6 \%$ \\
3 & Rendah & 43 & $43,4 \%$ \\
\hline & Jumlah & 99 & $100,00 \%$ \\
\hline
\end{tabular}

Berdasarkan Tabel 6 bahwa siswa memiliki kepercayaan diri pada kategori sedang sebanyak 56 siswa $(56,6 \%)$ dan pada kategori rendah sebanyak 43 siswa $(43,4 \%)$. Sedangkan pada kategori tinggi tidak ada. Sehingga kepercayaan diri siswa termasuk dalam kategori sedang.

Hal ini serupa dengan studi TIMSS (2012, p.338) yang menunjukkan bahwa dalam skala internasional sebanyak $45 \%$ siswa memiliki selfconfidence dalam kategori sedang kemampuan matematikanya. Sementara yang terjadi pada siswa di Indonesia berdasarkan studi TIMSS juga menguatkan bahwa mayoritas siswa dalam kategori self-confidence sedang sebanyak $52 \%$.

Berdasarkan strata sekolah diperoleh perbandingan rata-rata kepercayaan diri siswa pada masing-masing strata disajikan Tabel 7.

Tabel 7. Perbandingan Rata-Rata Kepercayaan Diri Siswa untuk Masing-Masing Strata Sekolah

\begin{tabular}{ccc}
\hline No. & Kategori & Rata-rata \\
\hline 1. & A & 33,35 \\
2. & B & 29,3 \\
3. & C & 28,94 \\
\hline
\end{tabular}

Tabel 7 menunjukkan bahwa sekolah dengan kategori A memperoleh rata-rata tertinggi sebesar 33,35. Kemudian sekolah dengan kategori B memperoleh rata-rata sebesar 29,3. Sementara sekolah dengan rata-rata terendah adalah sekolah kategori C. Hal ini berarti sekolah dengan kategori A memiliki kepercayaan diri dalam pembelajaran Matematika lebih tinggi dibandingkan sekolah dengan kategori B dan C.

Tabel 8. Hasil Kategorisasi Aspek Kepercayaan Diri

\begin{tabular}{lccc}
\hline \multicolumn{1}{c}{ Aspek } & \multicolumn{3}{c}{ Hasil } \\
\cline { 2 - 4 } & Tinggi & Sedang & Rendah \\
\hline - Keyakinan akan & $0 \%$ & $64,6 \%$ & $35,4 \%$ \\
kemampuan diri & $0 \%$ & $54,5 \%$ & $45,5 \%$ \\
- Optimis & $0 \%$ & $76,8 \%$ & $23,2 \%$ \\
- Objektif & $0 \%$ & $68,7 \%$ & $31,3 \%$ \\
- Bertanggung & $0 \%$ & $26,3 \%$ & $73,7 \%$ \\
$\begin{array}{l}\text { - jawab } \\
\text { Rasional dan }\end{array}$ & 0 \\
\hline
\end{tabular}


Pythagoras, 13 (2), 2018 - 156

Gity Wulang Mandini, Hartono Hartono

Variabel kepercayaan diri dijelaskan berdasarkan 5 aspek diantaranya adalah keyakinan, optimis, objektif, bertanggung jawab dan rasional dan realistis oleh Lauster (Ghufron \& Risnawati, 2014, p.35). Berdasarkan pada Tabel 8 bahwa hasil kategorisasi kepercayaan diri pada aspek keyakinan akan kemampuan diri, optimis, objektif, dan bertanggung jawab berada pada kategori sedang. Sedangkan untuk kategori rasional dan realistis berada pada kategori rendah.

Dengan kepercayaan diri, siswa menjadi optimis dan tegar dalam menghadapi berbagai masalah yang dihadapi dalam proses pembelajaran dan mampu menyelesaikan permasalahan tersebut dengan mengoptimalkan segala kemampuan yang dimiliki oleh siswa (Ameliah et al, 2016, p. 10). Sehingga dengan sikap optimis siswa akan merasa mampu untuk menghadapi kesulitan-kesulitan yang ditemui. Hal ini sesuai dengan hasil kepercayaan diri siswa SMP di Kabupaten Wonosobo, yaitu siswa telah mampu berpikir optimis, objektif, bertanggung jawab, dan meyakini kemampuan dirinya. Namun siswa belum dapat berpikir secara rasional dan realistis, karena dalam menganalisa suatu masalah siswa belum mampu menggunakan pemikiran yang diterima akal dan sesuai dengan kenyataan.

Kepercayaan diri seorang siswa merupakan faktor internal yang mempengaruhi proses pembelajaran. Apabila siswa dalam proses pembelajaran mampu menyelesaikan permasalahan dengan mengoptimalkan segala kemampuan yang dimiliki oleh siswa, maka akan menumbuhkan rasa kepercayaan diri yang tinggi pada mata pelajaran matematika. Oleh karena itu, perlu adanya dukungan dari berbagai pihak dalam menciptakan rasa kepercayaan diri pada peserta didik dalam pembelajaran Matematika. Hal ini sesuai dengan pendapat Mastuti (2008, p.48) yang mengemukakan bahwa faktor-faktor yang mempengaruhi kepercayaan diri adalah orang tua, masyarakat, lingkungan dimana individu dibesarkan, teman sebaya dan konsep diri.

Selain dukungan dari orang tua, sekolah dan lingkungan, peserta didik juga dapat menumbuhkan rasa kepercayaan diri melalui diri sendiri. Sebagaimana yang dikemukakan oleh Hurlock (2003, p.59), bahwa cara untuk meningkatkan rasa percaya diri antara lain mampu berpikir lebih positif, mampu memacu motivasi diri, dapat membaca potensi diri, berani mengambil risiko, dan memahami bahwa kepercayaan diri mudah untuk diraih.

\section{SIMPULAN}

Kemampuan menyelesaikan soal HOTS model TIMSS siswa SMP Kabupaten Wonosobo dalam kategori sedang $(85,9 \%)$. Selanjutnya dilihat untuk masing-masing indikator dari soal HOTS model TIMSS, indikator memadukan/ mensintesis, menganalisis, memberikan alasan, dan menyelesaikan masalah non-rutin berada pada kategori sedang, hanya terdapat 1 indikator yang berada pada kategori rendah yaitu menggeneralisasi. Sedangkan untuk kepercayaan diri siswa SMP di Kabupaten Wonosobo berada pada kategori sedang $(56,6 \%)$ dan bila dilihat untuk masing-masing aspek, bahwa aspek keyakinan akan kemampuan diri, optimis, objektif, dan bertanggung jawab berada pada kategori sedang, untuk aspek rasional dan realistis berada pada kategori rendah.

\section{DAFTAR PUSTAKA}

Adiyanti, A. (2016). Mutu pendidikan matematika di Indonesia masih rendah. Diambil pada tanggal 20 Agustus 2016, dari http://ugm.ac.id/id/berita.

Ameliah, I. H., Munawaroh, M., \& Muchyidin, A. (2016). Pengaruh keingintahuan dan rasa percaya diri siswa terhadap hasil belajar matematika kelas VII MTs Negeri I Kota Cirebon. Jurnal Edukasi Matematika, 5(1), 9-21. DOI: http://dx.doi.org/10.24235/eduma.v5i1.59 8

Anderson, L. W. \& Krathwohl, D. R. (2001). A taxonomy for learning, teaching, and assessing: A revision of Bloom's taxonomy of educational objectives. New York, NY: Addison Wesley Longman.

Anonim. (2011). Peringkat pendidikan Indonesia turun. Diambil pada tanggal dari 20 Agustus 2016, dari http://edukasi.kompas.com/read/2011/03/ 03/04463810/peringkat.pendidikan.indone sia.turun

Ayuningtyas, N. \& Rahaju, E. B. (2014). Proses penyelesaian soal higher order thinking materi aljabar siswa SMP ditinjau berdasarkan kemampuan matematika siswa. Artikel dipublikasikan Universitas Negeri Surabaya.

Azwar, S. (2013). Penyusunan skala psikologi. Yogyakarta: Pustaka Belajar. 
Pythagoras, 13 (2), 2018 - 157

Gity Wulang Mandini, Hartono Hartono

Budiman, A., \& Jailani, J. (2014). Pengembangan instrumen asesmen Higher Order Thinking Skill (HOTS) pada mata pelajaran matematika SMP kelas VIII semester 1. Jurnal Riset Pendidikan Matematika, 1(2), 139-151.

doi:http://dx.doi.org/10.21831/jrpm.v1i2. 2671

Butkowski, J., Corrigan, C., Nemeth, T., \& Spencer, L. (1994). Improving student higher-order thinking skills in mathematics. Theses. Mathematics Education Research, Saint Xavier University-IRI, Fied-Based Master's Program.

Ghufron, M. N., \& Risnawita, R. (2010). Teoriteori psikologi. Yogyakarta: Ar-Ruzz Media.

Hurlock, E.B. (2003). Psikologi perkembangan, suatu pendekatan sepanjang rentang Kehidupan. (Alih bahasa: Istiwidayanti dan Soedjarwo). Jakarta: Erlangga.

King, F.J., Godson L., \& Rohani, F. (2013). Higher order thinking skills: definition teaching strategies, assessment. Center for Advancement of Learning and Assessment. Diambil pada tanggal 19 Agustus 2016, dari http://www.cala.fsu.edu/files/higher_orde r_thinking_skills.pdf.

Martyanti, A. (2016). Keefektifan pendekatan problem solving dengan setting STAD dan TAI ditinjau dari prestasi dan selfconfidence. Jurnal Riset Pendidikan Matematika, 3(1), 1-15. doi:http://dx.doi.org/10.21831/jrpm.v3i1. 9825
Mastuti, I. (2008). 50 Kiat percaya diri. Jakarta: Hi Fest Publising.

McElmeel, S. L. (2002). Character education: A book guide for teachers, librarians, and parents. Greenwood Village, Colorado: Greenwood Publishing Group, Inc.

Mullis, I. V. S., Martin, M. O., Foy, P., \& Arora, A. (2012). TIMSS 2011 international result in mathematics. Chestnut Hill, MA: TIMSS \& PIRLS International Study Center Lynch School of Education, Boston College.

Mullis, I. V.S, Martin, M. O., Ruddock, G. J., O’Sullivan, C. Y., \& Preuschoff, C. (2009). TIMSS 2011 assessment frameworks. Amsterdam: International Association for the Evaluation of Educational Achievement (IEA).

Riadi, A. \& Retnawati, H. (2014). Pengembangan perangkat pembelajaran untuk meningkatkan HOTS pada kompetensi bangun ruang sisi datar. Pythagoras: Jurnal Pendidikan Matematika, 9(2), 126-135. doi: http://dx.doi.org/10.21831/pg.v9i2.9074

Romadhon, S. (2015). Analisis kemampuan komunikasi matematis siswa SMP pada materi kubus dan balok. Ekuivalen, 167172.

Thomas, A. \& Thorne, G. (2009). Higher level thinking-it's hot! Diambil pada tanggal 19 April 2016, dari http://www.cdl.org/articles/higher-orderthinking-its-hot/.

Walgito, B. (2004). Pengantar psikologi umum. Yogyakarta: Andi 